\title{
Model Promosi Penjualan dan Citra Perusahaan dalam Pengembangan Loyalitas Nasabah PT Bank Negara Indonesia (Persero) Tbk. Kantor Cabang Utama Tebet
}

Model Sales Promotion and Corporate Image Development of Customer Loyalty in PT Bank Negara Indonesia (Persero) Tbk. Main Branch Office of Tebet

\section{Annisa Milana ${ }^{*}$, Musa Hubeis ${ }^{2}$ dan Euis Sunarti ${ }^{3}$}

\author{
${ }^{1}$ Program Magister Industri Kecil Menengah Sekolah Pascasarjana Institut Pertanian Bogor \\ ${ }^{2}$ Departemen Manajemen, Fakultas Ekonomi dan Manajemen Institut Pertanian Bogor \\ Jl. Kamper, Kampus IPB Darmaga, Bogor 16680 \\ ${ }^{3}$ Departemen Ilmu Keluarga dan Konsumen, Fakultas Ekologi Manusia Institut Pertanian Bogor \\ Jl. Lingkar Kampus IPB Darmaga, Bogor 16680
}

\begin{abstract}
ABSTRAK
Bank-bank komersial di Indonesia saat ini beroperasi dalam lingkungan bisnis yang sangat dinamis, yaitu lingkungan modern kompetitif, maka bank menciptakan nilai dengan modal relasional. Oleh karena itu, loyalitas nasabah menjadi komponen yang paling penting bagi keberhasilan bank. Tujuan dari penelitian ini adalah untuk menganalisis pengaruh promosi penjualan dan citra perusahaan terhadap loyalitas nasabah. Untuk mencapai tujuan tersebut, telah dilakukan survei persepsi kepada 80 nasabah BNI Taplus PT BNI (Persero) Tbk. Kantor Cabang Utama Tebet. Untuk menilai pengaruh peubah yang diteliti digunakan metode regresi linear berganda (multiple linear regressions). Hasil penelitian menunjukkan bahwa promosi penjualan dan citra perusahaan memiliki pengaruh nyata terhadap loyalitas nasabah. Dengan demikian, upaya peningkatan loyalitas nasabah bank dapat dilakukan melalui promosi penjualan yang efektif dan pembangunan citra perusahaan yang lebih baik.
\end{abstract}

Kata kunci: bank, citra perusahaan, loyalitas nasabah, promosi penjualan

\section{ABSTRACT}

The commercial banks in Indonesia are currently operating in a more dynamic business environment than before. In the modern competitive environment banks create the value generally using the relational capital. Thus, customer loyalty is the most vital component for bank success in a market. The purpose of the paper is to analyze the effect of sales promotion and corporate image on customer loyalty. To achieve this goal, 80 customers of BNI Taplus account holders of PT BNI (Persero) Tbk. Tebet Main Branch Office were surveyed. Multiple linear regressions technique was used to assess the effect of among the variables under investigation. The findings of this study have shown significant relationships effect of among the sales promotion, corporate image and customer loyalty. Customer loyalty can, therefore, be generated through effective sales promotion and high corporate image.

Key words: bank, corporate image, customer loyalty, sales promotion

\section{LATAR BELAKANG}

Pertumbuhan bisnis perbankan yang semakin dinamis telah membuat persaingan antar bank, baik bank pemerintah maupun bank swasta, tidak dapat dihindari. Hal ini sejalan dengan apa yang dinyatakan oleh Lovelock (2004), bahwa sektor jasa merupakan industri yang paling cepat mengalami perubahan, yang pada akhirnya berdampak pada semakin meningkatnya iklim kompetisi di dalamnya.

Dalam lingkungan persaingan bisnis yang semakin tajam tersebut, nasabah yang loyal menjadi kunci utama bagi kelangsungan hidup

\section{*) Korespondensi:}

BNI Divisi BIN, Jl. Jenderal Sudirman Kav. 1, Jakarta 10220; e-mail: annisa.milana@bni.co.id 
bank. Pengembangan produk-produk perbankan hampir sangat mudah untuk ditiru. Bahkan pelayanan yang diberikannya hampir identik. Oleh karena itu, nasabah yang loyal merupakan alat yang efektif dan potensial untuk digunakan bank memperoleh keuntungan strategik dan bertahan dalam lingkungan yang kompetitif saat ini.

Berdasarkan hasil survei indeks loyalitas pelanggan yang dilakukan oleh MarkPlus Insight pada akhir tahun 2013 terhadap lebih dari 2.900 responden yang tersebar di enam kota besar di Indonesia, yaitu Jakarta, Bandung, Semarang, Surabaya, Medan dan Makassar, terindikasi bahwa beberapa konsumen perbankan di Indonesia, termasuk BNI mengalami kesulitan dalam menjaga dan meningkatkan loyalitas nasabah. Hasil survei MarkPlus Insight memperlihatkan bahwa pada akhir tahun 2013 loyalitas nasabah BNI mengalami penurunan dibandingkan dengan pencapaian tahun sebelumnya (Indonesian Bank Loyalty Index, 2014).

Promosi penjualan adalah alat dan event pemasaran yang didesain untuk menstimulus penjualan secara lebih cepat dan lebih besar dalam jangka waktu terbatas (Kotler, 2007). Dalam berbagai penelitian terdahulu promosi penjualan dalam kaitannya dengan perilaku pelanggan, ditemukan promosi penjualan dianggap mampu memengaruhi berbagai aspek dari perilaku keputusan membeli hingga loyalitas pelanggan (Bridges et al, 2009; Nagar, 2010; Omotayo, 2011). Bridges et al (2009) menyebutkan bahwa promosi penjualan merupakan faktor penting dalam menentukan loyalitas pelanggan dan mampu memengaruhi secara langsung minat pelanggan untuk melakukan pembelian. Hasil penelitian Bridges et al. (2009) ini diperkuat oleh penelitian terbaru Omotayo (2011) yang menemukan bahwa promosi penjualan berpengaruh positif terhadap minat pelanggan untuk melakukan pembelian ulang pada masa mendatang. Begitu pula Nagar (2010) menemukan promosi penjualan berhubungan positif dengan loyalitas merek (brand loyalty).

Menurut Grunig (2003) citra perusahaan bersinonim dengan pesan, reputasi, persepsi, kredibilitas, keyakinan, komunikasi dan hubungan. Sementara Lai et al. (2009) mendefinisikan citra perusahaan sebagai persepsi mengenai perusahaan yang ada dalam ingatan pelanggan dan berfungsi sebagai filter yang memengaruhi persepsi mengenai kegiatan perusahaan. LeBlanc dan Nguyen (2002) menyatakan bahwa citra perusahaan berkaitan erat dengan perilaku dan atribut perusahaan yang bersifat fisik seperti nama perusahaan, arsitektur, keberagaman produk atau jasa dan kesan terhadap mutu yang dikomunikasikan oleh setiap orang yang berinteraksi dengan klien perusahaan.

Secara empiris citra perusahaan telah diakui sebagai faktor penentu dari kepuasan dan loyalitas pelanggan $(\mathrm{Wu}, 2011)$. Dalam penelitiannya, Wu (2011) menemukan bahwa citra perusahaan berhubungan positif, baik secara langsung maupun tidak langsung dengan loyalitas pelanggan. Hasil ini konsisten dengan teori yang menyebutkan bahwa jika pelanggan menyukai citra perusahaan, maka pelanggan cenderung meningkatkan loyalitasnya. Begitu pula dalam penelitian yang dilakukan oleh Wang et al. (2012) ditemukan bahwa citra perusahaan memiliki hubungan langsung dan berpengaruh nyata terhadap loyalitas pelanggan. Namun demikian, berbeda dengan hasil-hasil penelitian tersebut, Davies dan Chun (2010) menemukan bahwa citra perusahaan tidak memiliki pengaruh secara langsung terhadap loyalitas pelanggan, akan tetapi berpengaruh tidak langsung melalui kepuasan pelanggan.

Berbeda dengan hasil-hasil penelitian di atas, citra brand dan bisnis BNI sebagai bank unggul, terkemuka dan terdepan dalam layanan dan kinerja di Indonesia ditambah gencarnya program promosi penjualan yang dilakukan oleh BNI (tercatat anggaran promosi tahun 2013 meningkat sampai dengan 112 miliar rupiah atau 15,01\% dibandingkan tahun 2012), ternyata tidak mendorong terjadinya peningkatan loyalitas nasabah terhadap BNI, dimana terbukti menurut Indonesian Bank Loyalty Index loyalitas nasabah BNI malah mengalami penurunan (Indonesian Bank Loyalty Index, 2014).

Tujuan penelitian ini adalah (1) Menganalisis promosi penjualan, citra perusahaan dan loyalitas nasabah PT Bank Negara Indonesia (Persero) Tbk. Kantor Cabang Utama (KCU) Tebet, (2) Menganalisis pengaruh promosi penjualan dan citra perusahaan terhadap persepsi manfaat, persepsi kemudahan dan persepsi keamanan terhadap loyalitas nasabah PT Bank Negara Indonesia (Persero) Tbk. KCU Tebet.

\section{METODOLOGI}

Penelitian ini bersifat deskriptif untuk menggambarkan mengenai pelaksanaan Promosi penjualan dan Citra Bank serta Loyalitas Nasabah 
PT Bank Negara Indonesia (Persero) Tbk, disamping Kantor Cabang Utama Tebet. Penelitian verifikatif unuk meneliti hubungan peubah independen dan peubah dependen, yaitu hubungan Promosi penjualan dan Citra Bank dengan Loyalitas nasabah. Untuk itu digunakan metode explanatory survey terhadap unit analisis, yaitu para nasabah PT Bank Negara Indonesia (Persero) Tbk. Kantor Cabang Utama Tebet.

Pengumpulan data dilakukan dengan kuesioner. Pengisian kuesioner dilakukan secara langsung oleh responden dengan memberi tanda pada jawaban yang telah disediakan. (angket tertutup dan terstruktur), menjawab selain dari jawaban yang telah disediakan dengan skala semantik differensial dengan skala penilaian 7 (tujuh) poin yang menyatakan secara verbal dua kutub (bipolar) dari penilaian yang berlawanan.

Dalam penelitian ini yang menjadi populasi adalah Nasabah PT Bank Negara Indonesia (Persero) Tbk. KCU Tebet. Untuk mendapatkan contoh yang representatif dalam penelitian ini digunakan teknik pengambilan contoh secara purposive sampling. Populasi sasaran adalah nasabah BNI Taplus PT Bank Negara Indonesia (Persero) Tbk. KCU Tebet yang berjumlah 362.671 nasabah, dengan contoh diambil sebanyak 80 orang yang ditentukan berdasarkan teknik penentuan ukuran contoh yang menggunakan rumus berikut (Bungin, 2009):

Dimana:

$$
n=\frac{N}{N d^{2}+1}
$$

$$
\begin{aligned}
\mathrm{n}= & \text { Jumlah contoh } \\
\mathrm{N}= & \text { Populasi } \\
\mathrm{d}= & \text { Tingkat kesalahan penarikan contoh } \\
& 11 \% \text { dan kepercayaan } 90 \%
\end{aligned}
$$

Dari jumlah populasi tersebut dengan tingkat kelonggaran ketidaktelitian $11 \%$, maka dengan menggunakan rumus di atas diperoleh contoh:

$$
n=\frac{362.671}{1+362.671(0,11)^{2}}=79,70 \sim 80
$$

Untuk memudahkan pengolahan data, maka dilakukan operasionalisasi peubah, yaitu :

1. Peubah Independen (Peubah Bebas atau Peubah X)

Peubah independen dalam penelitian ini terdiri dari: Promosi penjualan $\left(\mathrm{X}_{1}\right)$ terdiri dari Hadiah langsung/Souvenir dan Undian Berhadiah; dan Citra Perusahaan $\left(\mathrm{X}_{2}\right)$ meliputi dimensi citra fungsional dan emosional.
2. Peubah Dependent (Peubah Terikat atau Peubah Y)

Peubah dependen dalam penelitian ini adalah Loyalitas Nasabah yang diukur melalui sikap loyalitas (attitudinal loyalty) dan perilaku loyalitas (behavioral loyalty).

Penelitian ini menggunakan analisis kuantitatif dengan metode analisis regresi linear berganda menggunakan bantuan statistical package for social science (SPSS) 19. Metode analisis regresi linear berganda adalah analisis yang digunakan untuk mengukur pengaruh dua atau lebih peubah independen terhadap satu peubah dependen dengan rumus (Sarjono dan Julianita, 2011) sebagai berikut:

$$
\mathrm{Y}=\mathrm{a}+\mathrm{b}_{1} \mathrm{X}_{1}+\mathrm{b}_{2} \mathrm{X}_{2}+\mathrm{e}
$$

Keterangan:

$\mathrm{Y}=$ peubah dependen

a $=$ konstanta

$\mathrm{b}_{1,2}=$ koefisien regresi

$\mathrm{X}_{1,2}=$ peubah independen

\section{HASIL DAN PEMBAHASAN}

Untuk menggambarkan karakteristik responden, yaitu nasabah BNI Taplus PT Bank Negara Indonesia (Persero) Tbk. Kantor Cabang Utama Tebet yang masuk dalam kelompok contoh penelitian, pertanyaan yang diajukan dalam kuesioner terdiri atas: jenis kelamin, usia, tingkat pendidikan dan pekerjaan.

Karakteristik responden berdasarkan jenis kelamin terdiri dari 37\% (30 orang) pria dan 63\% wanita (50 orang). Hal ini karena budaya di masyarakat, dimana kebiasaan yang mengatur keuangan dalam rumah tangga pada umumnya adalah wanita sebagai ibu rumah tangga, sehingga wanita pula yang lebih mengetahui seberapa besar kebutuhan untuk keperluaan rumah tangga dan seberapa besar yang dapat disisihkan untuk ditabungkan guna keperluan keluarga di masa mendatang, terutama untuk keper-luan biaya pendidikan anak-anak nantinya.

Hasil analisis karakteristik responden berdasarkan usia terlihat bahwa nasabah yang paling banyak berusia 31-40 tahun sebanyak 32 orang $(40 \%)$, dimana nasabah lebih memikirkan masa depan untuk anak-anaknya, karena dengan menabung dapat mempersiapkan biaya pendidikan anak-anaknya sedini mungkin dan yang paling sedikit adalah responden yang berusia 51-60 tahun sebanyak 11 orang (15\%), dimana nasabah menabung untuk dapat menunaikan ibadah haji. 
Hasil analisis karakteristik responden menurut jenis pekerjaannya, terlihat bahwa nasabah yang paling banyak adalah nasabah dengan jenis pekerjaan sebagai PNS atau pegawai di BUMN sebanyak 42 orang (53\%), dimana nasabah menabung karena bank memberikan kemudahan dalam memperoleh pinjaman dana dan yang paling sedikit adalah responden ibu rumah tangga 9 orang (11\%), dimana nasabah menabung karena keperluan pendidikan anak atau keperluan hari tua

\section{Hasil Pengujian Mutu Data}

\section{Uji Validitas}

Berdasarkan hasil pengolahan menggunakan teknik korelasi Product Moment dari Pearson diperoleh hasil uji validitas seperti dimuat pada Tabel 1.

Tabel 1. Hasil uji validitas kuesioner promosi penjualan

\begin{tabular}{lccc}
\hline \multicolumn{1}{c}{ Pernyataan } & $\begin{array}{c}\text { Indeks } \\
\text { Validitas }\end{array}$ & $\begin{array}{c}\text { Nilai } \\
\text { Kritis }\end{array}$ & $\begin{array}{c}\text { Kete- } \\
\text { rangan }\end{array}$ \\
\hline - $\begin{array}{l}\text { Daya tarik hadiah } \\
\text { langsung/souvenir } \\
\text { - Transparansi undian } \\
\text { berhadiah }\end{array}$ & 0,913 & & \\
- $\begin{array}{l}\text { Daya tarik undian } \\
\text { berhadiah }\end{array}$ & 0,856 & 0,30 & Valid \\
\hline
\end{tabular}

Berdasarkan Tabel 1 diketahui bahwa koefisien korelasi masing-masing butir pernyataan pada peubah promosi penjualan menunjukkan nilai lebih besar dari koefisien korelasi kritis $(0,30)$, maka masing-masing butir pernyataan yang terdapat dalam kuesioner peubah promosi penjualan adalah valid dan layak digunakan sebagai acuan dalam pengukuran persepsi tentang promosi penjualan yang dilakukan oleh PT Bank Negara Indonesia

Berdasarkan Tabel 2 diketahui bahwa koefisien korelasi masing-masing butir pernyataan pada peubah citra perusahaan menunjukkan nilai lebih besar dari koefisien korelasi kritis $(0,30)$, maka masing-masing butir pernyataan yang terdapat dalam kuesioner peubah citra perusahaan adalah valid dan layak digunakan sebagai acuan dalam pengukuran persepsi tentang citra PT Bank Negara Indonesia (Persero) Tbk.

Berdasarkan Tabel 3 diketahui bahwa koefisien korelasi masing-masing butir pernyataan pada peubah loyalitas nasabah menunjukkan nilai lebih besar dari koefisien korelasi kritis $(0,30)$, maka masing-masing butir pernyataan yang terdapat dalam kuesioner peubah loyalitas nasabah adalah valid dan layak digunakan sebagai acuan dalam pengukuran persepsi loyalitas nasabah.

Tabel 2. Hasil uji validitas kuesioner citra perusahaan

\begin{tabular}{|c|c|c|c|}
\hline Pernyataan & $\begin{array}{c}\text { Indeks } \\
\text { Validitas }\end{array}$ & $\begin{array}{l}\text { Nilai } \\
\text { Kritis }\end{array}$ & $\begin{array}{l}\text { Kete- } \\
\text { rangan }\end{array}$ \\
\hline Layanan cepat & 0,695 & & \\
\hline Lokasi kantor strategik & 0,674 & & \\
\hline Menghargai nasabah & 0,760 & & \\
\hline $\begin{array}{l}\text { Memberikan informasi } \\
\text { lengkap }\end{array}$ & 0,603 & & \\
\hline Bersahabat dan helpful & 0,629 & & \\
\hline Mengenal nasabah & 0,729 & & \\
\hline $\begin{array}{l}\text { Memahami kebutuhan } \\
\text { nasabah }\end{array}$ & 0,706 & & \\
\hline $\begin{array}{l}\text { Berinteraksi aktif } \\
\text { terhadap nasabah }\end{array}$ & 0,707 & & \\
\hline Ramah & 0,689 & & \\
\hline $\begin{array}{l}\text { Memiliki pegawai } \\
\text { kompeten }\end{array}$ & 0,802 & & \\
\hline $\begin{array}{l}\text { Memiliki manajemen } \\
\text { profesional }\end{array}$ & 0,748 & 0,30 & Valid \\
\hline $\begin{array}{l}\text { Dijamin oleh } \\
\text { pemerintah }\end{array}$ & 0,530 & & \\
\hline Layanan progresif & 0,499 & & \\
\hline $\begin{array}{l}\text { Mesin ATM mudah } \\
\text { ditemui }\end{array}$ & 0,511 & & \\
\hline $\begin{array}{l}\text { Jam buka tambahan } \\
\text { (week end) }\end{array}$ & 0,436 & & \\
\hline Suku bunga tinggi & 0,540 & & \\
\hline $\begin{array}{l}\text { Biaya administrasi } \\
\text { murah }\end{array}$ & 0,388 & & \\
\hline $\begin{array}{l}\text { Memiliki reputasi yang } \\
\text { bagus }\end{array}$ & 0,626 & & \\
\hline $\begin{array}{l}\text { Memiliki kedekatan } \\
\text { secara personal }\end{array}$ & 0,504 & & \\
\hline
\end{tabular}

Tabel 3. Hasil uji validitas kuesioner loyalitas nasabah

\begin{tabular}{lccc}
\hline \multicolumn{1}{c}{ Pernyataan } & $\begin{array}{c}\text { Indeks } \\
\text { Validitas }\end{array}$ & $\begin{array}{c}\text { Nilai } \\
\text { Kritis }\end{array}$ & $\begin{array}{c}\text { Kete- } \\
\text { rangan }\end{array}$ \\
\hline $\begin{array}{l}\text { Melakukan transaksi } \\
\text { secara teratur }\end{array}$ & 0,710 & & \\
$\begin{array}{l}\text { Menggunakan } \\
\text { produk lain diluar }\end{array}$ & 0,690 & & \\
$\begin{array}{l}\text { lini produk } \\
\text { Mereferensikan } \\
\text { kepada orang lain }\end{array}$ & 0,793 & 0,30 & valid \\
$\begin{array}{l}\text { Tidak terpengaruh } \\
\text { daya tarik produk } \\
\text { pesaing }\end{array}$ & 0,719 & & \\
\hline
\end{tabular}

\section{Uji Reliabilitas}

Berdasarkan hasil perhitungan dengan menggunakan teknik korelasi belah dua (split-half) 
Spearman-Brown diperoleh hasil uji reliabilitas yang dimuat pada Tabel 4. Berdasarkan Tabel 4 diketahui bahwa koefisien reliabilitas alat ukur untuk seluruh peubah dalam penelitian ini memiliki nilai lebih besar dari nilai kritis 0,7, maka semua alat ukur adalah reliabel, sehingga dapat digunakan untuk analisis lebih lanjut.

Tabel 4. Hasil uji reliabilitas kuesioner penelitian

\begin{tabular}{clcc}
\hline No. & \multicolumn{1}{c}{ Peubah } & $\begin{array}{c}\text { Koefisien } \\
\text { Reliabilitas }\end{array}$ & Keterangan \\
\hline 1 & Promosi Penjualan & 0,845 & \\
2 & Citra Perusahaan & 0,911 & Reliabel \\
3 & Loyalitas Nasabah & 0,881 & \\
\hline
\end{tabular}

\section{Pengujian Asumsi Klasik}

\section{Uji Normalitas}

Uji Normalitas bertujuan menguji apakah dalam model regresi peubah pengganggu atau residual memiliki distribusi normal. Untuk mendeteksi apakah residual berdistribusi normal atau tidak digunakan analisis Kolmogorof-Smirnov (KS) (Ghozali, 2011). Dari hasil uji normalitas Kolmogorof dapat dilihat bahwa nilai Kolmogorof-Smirnov $0,720>$ tingkat nyata 0,1 dan nilai peluang nyata $0,678>$ nilai nyata 0,05 , sehingga dapat disimpulkan data residual berdistribusi normal.

\section{Uji Multikolonieritas}

Uji Multikolonieritas bertujuan mengetahui apakah dalam model regresi ditemukan adanya korelasi antar peubah bebas (independen). Berdasarkan Uji Multikolonieritas, diperoleh hasil bahwa peubah promosi penjualan dan citra perusahaan bebas dari multikolonieritas yang ditunjukkan nilai tolerance $>0,10$ atau nilai VIF $<10$.

\section{Uji Heteroskedastisitas}

Uji Heteroskedastisitas bertujuan untuk menguji apakah dalam model regresi terjadi ketidaksamaan ragam dari residual satu pengamatan ke pengamatan yang lain. Berdasarkan Uji Heteroskedastisitas, diperoleh nilai korelasi peubah promosi penjualan dengan nilai mutlak residual model (error term) 0,044 dengan peluang nyata 0,696 dan nilai korelasi peubah citra perusahaan dengan nilai mutlak residual model (error term) 0,003 dengan peluang nyata 0,981. Nilai tersebut lebih besar dari 0,05, maka disimpulkan bahwa peubah promosi penjualan dan citra perusahaan bebas dari heteroskedastisitas.

\section{Estimasi Model Regresi Linear Berganda}

Analisis regresi linear berganda digunakan untuk meneliti pengaruh peubah dependen dengan beberapa peubah independen. Perhitungan persamaan regresi dilakukan dengan program SPSS 19. Hasil perhitungan koefisien regresi linear berganda disajikan pada Tabel 5 .

Tabel 5. Koefisien Regresi

\begin{tabular}{ccccccc}
\hline \multicolumn{7}{c}{ Coefficients(a) } \\
\hline \multirow{2}{*}{ Model } & $\begin{array}{c}\text { Unstandar- } \\
\text { dized } \\
\text { Coefficients }\end{array}$ & $\begin{array}{c}\text { Standar- } \\
\text { dized } \\
\text { Coefficients }\end{array}$ & $\mathrm{t}$ & Sig. \\
\cline { 3 - 5 } & $\mathrm{B}$ & $\begin{array}{c}\text { Std. } \\
\text { Error }\end{array}$ & Beta & & \\
\hline 1 & (Constant) & 2,272 & 4,123 & & 0,551 & 0,583 \\
& PROMOSI & 0,158 & 0,114 & 0,148 & 2,383 & 0,001 \\
& CITRA & 0,190 & 0,040 & 0,505 & 4,721 & 0,000 \\
\hline
\end{tabular}

a Dependent Variable: LOYALITAS

Berdasarkan Tabel 5 dihasilkan persamaan:

$$
\hat{Y}=2,272+0,158 x_{1}+0,190 x_{2}
$$

sehingga diperoleh persamaan regresi berikut:

\section{LOYALITAS $=2,272+0,158$ PROMOSI $+0,190$ CITRA}

Dari persamaan regresi tersebut dapat dijelaskan bahwa Konstanta (intersept) 2,272, artinya apabila peubah promosi penjualan dan citra perusahaan tidak berubah (konstan), maka loyalitas nasabah diperkirakan akan berada pada level 2,272.

Koefisien regresi promosi penjualan 0,158, artinya bahwa jika persepsi nasabah terhadap kegiatan promosi penjualan naik satu nilai dan peubah lain diasumsikan konstan, maka loyalitas nasabah diperkirakan akan naik 0,158. Nilai koefisien yang positif menunjukkan pengaruh searah promosi penjualan terhadap loyalitas nasabah. Dari hasil regresi dapat disimpulkan, bahwa semakin tinggi persepsi nasabah terhadap kegiatan promosi yang dilakukan oleh PT BNI (Persero) Tbk. KCU Tebet, maka akan semakin meningkatkan loyalitas nasabah.

Koefisien regresi citra perusahaan 0,190, artinya bahwa jika persepsi nasabah terhadap citra peusahaan naik satu nilai dan peubah lain diasumsikan konstan, maka loyalitas nasabah diperkirakan akan naik 0,190. Nilai koefisien yang positif menunjukkan pengaruh searah citra perusahaan terhadap loyalitas nasabah. Dari hasil regresi tersebut disimpulkan bahwa semakin tinggi persepsi nasabah terhadap citra PT BNI 
(Persero) Tbk. KCU Tebet, maka loyalitas nasabah akan semakin meningkat pula. Lizarraga (2010) dan Pina et al. (2006) menyebutkan bahwa citra perusahaan yang positif akan menuntun kepada pengenalan merek, meningkatkan loyalitas pelanggan serta meningkatkan reputasi perusahaan.

\section{Analisis Determinasi}

Koefisien determinasi $\left(\mathrm{R}^{2}\right)$ menunjukkan seberapa besar persentase peubah independen (promosi penjualan dan citra perusahaan) secara simultan dapat menjelaskan/menerangkan variasi peubah dependen (loyalitas nasabah). Hasil analisis koefisien determinansi disajikan pada Tabel 6.

Berdasarkan Tabel 6, nilai koefisien determinasi (Adjusted $\mathrm{R}$ Square) 0,637. Hasil ini menunjukkan persentase sumbangan pengaruh peubah promosi penjualan dan citra perusahaan terhadap peubah loyalitas nasabah $63,7 \%$. Artinya peubah promosi penjualan dan citra perusahaan dalam penelitian ini mampu menjelaskan 63,7\% perubahan variasi peubah loyalitas nasabah dan sisanya $(36,3 \%)$ dipengaruhi atau dijelaskan oleh peubah lain yang tidak diteliti dalam penelitian ini, seperti peubah bauran pemasaran, mutu layanan, kepuasan nasabah dan sebagainya.

Tabel 6. Koefisien determinasi

Model Summary(b)

\begin{tabular}{ccccc}
\hline Model & $\mathrm{R}$ & $\begin{array}{c}\mathrm{R} \\
\text { Square }\end{array}$ & $\begin{array}{c}\text { Adjusted } \\
\text { R Square }\end{array}$ & $\begin{array}{c}\text { Std. Error of } \\
\text { the Estimate }\end{array}$ \\
\hline 1 & $0,895 \mathrm{a}$ & 0,654 & 0,637 & 3,01244 \\
\hline a Predictors: (Constant), CITRA, PROMOSI \\
b Dependent Variable: LOYALITAS
\end{tabular}

\section{Analisis Korelasi}

Koefisien korelasi menunjukkan seberapa besar hubungan yang terjadi antara peubah independen (promosi penjualan dan citra perusahaan) secara simultan terhadap peubah dependen (loyalitas nasabah). Nilai $\mathrm{R}$ berkisar antara 0 sampai 1 , nilai semakin mendekati 1 berarti hubungan yang terjadi semakin kuat, sebaliknya nilai semakin mendekati 0 , maka hubungan yang terjadi semakin lemah.

Berdasarkan perhitungan, diketahui besarnya korelasi peubah independen (promosi penjualan dan citra perusahaan) dengan peubah dependen (loyalitas nasabah) 0,895. Korelasi yang diperoleh termasuk dalam kategori sangat kuat, artinya terdapat korelasi sangat kuat antara promosi penjualan dan citra perusahaan secara simultan dengan loyalitas nasabah.

\section{Pengaruh Promosi Penjualan terhadap Loyalitas Nasabah}

Hasil penelitian mengindikasikan bahwa peningkatan atau penurunan Promosi Penjualan selama periode penelitian mempengaruhi Loyalitas Nasabah PT BNI (Persero) Tbk. KCU Tebet secara nyata, yaitu semakin efektif Promosi Penjualan yang dilakukan oleh PT BNI (Persero) Tbk. KCU Tebet akan mendorong peningkatan Loyalitas Nasabah. Hasil penelitian ini mendukung pendapat para ahli yang menyebutkan bahwa promosi penjualan memiliki peranan strategik untuk menjaga loyalitas nasabah. Fungsi dari promosi penjualan bukan hanya untuk mendorong pembelian ulang terhadap produk atau jasa, melainkan juga memperkuat loyalitas pelanggan (Nagar, 2010). Oleh sebab itu, PT BNI (Persero) Tbk. KCU Tebet secara gencar terus melakukan berbagai strategi promosi penjualan atas produk-produk keuangannya, terutama produk tabungan agar mampu menjaring sekaligus mempertahankan loyalitas nasabahnya secara lebih baik.

Tercatat dalam dua tahun terakhir, biaya promosi PT BNI (Persero) Tbk. KCU Tebet mengalami peningkatan secara nyata. Sebagian besar praktek promosi penjualan yang dilakukan oleh PT BNI (Persero) Tbk. KCU Tebet ditujukan kepada nasabah tabungan, dengan alasan tabungan adalah dana murah bagi bank, mengingat bunga yang diberikan sangat rendah. Disamping itu produk tabungan adalah produk perbankan yang masih sangat potensial dikembangkan, karena pemegang rekening tabungan di Indonesia belum mencapai setengah dari populasi. Hasil penelitian ini memperkuat hasil penelitian sebelumnya yang dilakukan oleh Bridges et al. (2009), Nagar (2010) dan Omotayo (2011) yang menemukan bahwa promosi penjualan adalah faktor penting dalam menentukan loyalitas pelanggan dan mampu memengaruhi secara langsung minat pelanggan untuk melakukan pembelian ulang pada masa mendatang.

\section{Pengaruh Citra Perusahaan terhadap Loyalitas Nasabah}

Hasil penelitian ini mengindikasikan bahwa peningkatan atau penurunan Citra Perusahaan selama periode penelitian memengaruhi Loyalitas Nasabah PT BNI (Persero) Tbk. KCU Tebet secara 
nyata, yaitu semakin tinggi Citra Perusahaan PT BNI (Persero) Tbk. KCU Tebet, maka semakin tinggi pula Loyalitas Nasabahnya. Citra perusahaan sebagai persepsi mengenai perusahaan yang ada dalam ingatan pelanggan dan berfungsi sebagai filter yang memengaruhi persepsi mengenai kegiatan perusahaan (Lai et al, 2009). Hasil ini mendukung pendapat para ahli yang menyebutkan bahwa citra perusahaan menjadi dasar pertimbangan dalam pengambilan keputusan pelanggan, serta merupakan faktor penentu dari kepuasan dan loyalitas pelanggan ( $\mathrm{Wu}, 2011)$. Hasil tersebut memperkuat hasil penelitian $\mathrm{Wu}$ (2011) dan Wang et al (2012) yang menemukan bahwa citra perusahaan mempunyai hubungan langsung dan berpengaruh nyata terhadap loyalitas pelanggan. Citra perusahaan yang baik juga dapat melemahkan pengaruh negatif dari pesaing dan membuat perusahaan mampu untuk mencapai laba lebih tinggi (Pina et al, 2006). Hasil penelitian ini berbeda dengan hasil penelitian Davies dan Chun (2010) yang menemukan bahwa citra perusahaan tidak memiliki pengaruh secara langsung terhadap loyalitas pelanggan, akan tetapi berpengaruh tidak langsung melalui kepuasan pelanggan.

\section{Pengaruh Promosi Penjualan dan Citra Perusahaan terhadap Loyalitas Nasabah}

Hasil penelitian mengindikasikan bahwa Promosi Penjualan dan Citra Perusahaan secara simultan selama periode penelitian memengaruhi Loyalitas Nasabah PT BNI (Persero) Tbk. KCU Tebet secara nyata. Persentase sumbangan pengaruh peubah Promosi Penjualan dan Citra Perusahaan secara simultan terhadap peubah Loyalitas Nasabah 63,7\% dan sisanya (36,3\%) dipengaruhi atau dijelaskan oleh peubah lain yang tidak diteliti dalam penelitian ini (bauran pemasaran, bauran promosi, mutu pelayanan, kepuasan nasabah dan lain sebagainya).

\section{Implikasi Manajerial}

Temuan penelitian ini memberikan implikasi manajerial yang penting dalam rangka mengembangkan loyalitas nasabah bank secara lebih efektif, yaitu:

1. Manajemen PT BNI (Tbk) KCU Tebet perlu mengembangkan dan memelihara aktivitas hubungan bisnis yang akan menciptakan loyalitas nasabah.

2. Manajemen PT BNI (Tbk) KCU Tebet perlu melakukan peningkatan kualitas manajemen dan pelayanan secara berkesinambungan demi terciptanya citra yang semakin baik, sehingga diharapkan kepuasan dan loyalitas nasabah akan terus meningkat.

3. Disamping citra perusahaan, strategi promosi penjualan yang diterapkan secara tepat akan mampu meningkatkan loyalitas nasabah terhadap bank. Melalui peningkatan citra perusahaan yang dibantu oleh strategi promosi penjualan efektif akan lebih mudah bagi bank untuk menciptakan loyalitas nasabah.

Poin lainnya, nasabah tabungan lebih tertarik kepada pendekatan promosi penjualan yang ditawarkan oleh bank dibandingkan dengan citra perusahaan. Dengan demikian manajer PT BNI (Tbk) KCU Tebet perlu melakukan berbagai inovasi dalam menawarkan promosi penjualan secara lebih menarik lagi, sehingga bank memiliki keunggulan kompetitif di hadapan nasabah, yang pada akhirnya mendorong peningkatan loyalitas nasabah.

\section{KESIMPULAN}

1. Promosi penjualan melalui pemberian hadiah langsung/souvenir dan program undian berhadiah telah diterapkan dengan baik oleh PT BNI (Persero) Tbk. KCU Tebet; Citra perusahaan yang dimiliki telah mendapatkan apresiasi baik dari nasabah BNI Taplus; Loyalitas nasabah BNI Taplus PT BNI (Persero) Tbk. KCU Tebet yang diindikasikan melalui kesediaan melakukan transaksi secara teratur, membeli antar lini produk dan jasa, merekomendasikan kepada orang lain dan menunjukkan kekebalan terhadap tarikan dari pesaing berada pada tingkat baik.

2. Promosi penjualan dan citra perusahaan berpengaruh nyata, baik parsial maupun simultan terhadap loyalitas nasabah BNI Taplus PT BNI (Persero) Tbk. Kantor Cabang Utama Tebet. Hal ini dapat menjelaskan bahwa promosi penjualan dan citra perusahaan memiliki daya tarik kuat bagi nasabah bank, baik melakukan transaksi pada produk inti maupun mencoba produk baru lainnya, serta bersedia setia dan menolak berpindah ke bank lain, jika merasa puas terhadap citra bank yang menjadi langganannya bahkan lebih jauh bersedia merekomendasikan bank tersebut kepada orang lain 


\section{DAFTAR PUSTAKA}

Bridges, E., Briesch. R. A. and Yim, C. K. 2009. Effects of Prior Brand Usage and Promotion on Consumer Promotion Response. Journal of Retailing, 82(4): 295-307.

Bungin, B. 2009. Penelitian Kualitatif. Kencana, Jakarta.

Davies, G. and Chun, R. 2010. Gaps Between the Internal and External Perceptions of the Corporate Brand. Corporate Reputation Review, 5: 144-158.

Ghozali, I. 2011. Aplikasi Analisis Multivariate dengan Program SPSS. Semarang: BP Universitas Diponegoro

Grunig, J.E. 2003. Excellence in Public Relations and Communication Management. London: Lawrence Erl-baum Associate Publisher.

Indonesian Bank Loyalty Index. 2014. Indonesian Bank Loyalty Index 2014. Markplus Insight, Jakarta.

Lai, F., Griffin, M., and Babin, B.J. 2009. How Quality, Value, Image, and Satisfaction Create Loyalty. Journal of Business Research, 62(10): 980-986.

Leblanc, G. and Nguyen, N. 2002. Corporate Image and Corporate Reputation in Customers' Retention Decisions in Services. Journal of Retailing and Consumer Services, 8: 227-236.

Lizarraga, I. 2010. Benefits of Corporate Societal Marketing. Journal of Consumer Marketing, 3: 205-230.
Lovelock, C. 2004. Service Marketing and Management. Prentice Hall, New Jersey.

Kotler, P. 2007. Manajemen Pemasaran, Analisis Perencanaan, Pengendalian, Prentice Hall, Edisi Bahasa Indonesia. Salemba Empat, Jakarta.

Nagar, K. 2010. Evaluating the Effects of Consumer Sales on Brand Loyal and Brand Switching segments. VISSION-Journal of Business Perspective, 13(4): 35-48.

Omotayo, O.A. 2011. Sales Promotion and Consumer Loyalty: A Study of Nigerian Financial Industry. Journal of Competitiveness, 3(1): 73-84.

Pina, J. M., Martinez, E., De Chernatony, L., and Drury, S. 2006. The Effect of Service Brand Extensions on Corporate Image. An Empirical Model. European Journal of Marketing, 1(2): 174-197.

Sarjono, H. dan W. Julianita. 2011. SPSS vs LISREL: Sebuah Pengantar, Aplikasi untuk Riset. Salemba Empat, Jakarta.

Wang, C.M., Tu, Y.T, and Chang, H.C. 2012. Corporate Brand Image and Customer Satisfaction on Loyalty: An Empirical Study of Financial Service in Taiwan. Journal of Social and Development Sciences, 3(1): 24-32.

$\mathrm{Wu}$, C. C. 2011. The Impact of Corporate Brand Image on Service Quality, Satisfaction and Loyalty. African Journal of Business Management, 5(12): 4873-4882. 